\begin{tabular}{|c|c|c|}
\hline $\mathrm{S}$ & $\begin{array}{c}\text { Proceeding } \\
\text { International Conference on Islamic Educational Guidance and Counseling } \\
\text { 9 December 2021 } \\
\text { E-ISSN: } 2827-9581 \\
\text { Website: http://conference.iainsalatiga.ac.id/index.php/iciegc }\end{array}$ & $\begin{array}{l}\text { Hele } 191-206 \\
\text { Hal. }\end{array}$ \\
\hline
\end{tabular}

\title{
INTERNALISASI NILAI AKHLAQUL KARIMAH DALAM PEMBELAJARAN AQIDAH AKHLAK PADA SISWA KELAS VI DI MI ISLAMIYAH 1 MAJASEM KECAMATAN KENDAL KABUPATEN NGAWI
}

\author{
Zikry Septoyadi ${ }^{1}$, Nor Azyan Nafisah ${ }^{2}$, Vita Lastriana Candrawati ${ }^{3}$, Junanah ${ }^{4}$ \\ 1,3,4 Islam Universitas Islam Indonesia \\ ${ }^{2}$ Institut Agama Islam Negeri Ponorogo
}

\begin{tabular}{l}
\hline \hline Informasi Artikel \\
\hline Penulis Korespondensi: \\
Zikry Septoyadi, \\
Email: \\
Zikryseptoyadi@gmail.com
\end{tabular}

Zikryseptoyadi@gmail.com

\begin{abstract}
This study aims to (1) determine the morals and character possessed by students, especially class VI at MI Islamiyah 1 Majasem, Kendal sub-district, Ngawi district. (2) To find out how the process of internalizing and applying the values of Akhlaqul Karimah in Aqidah Akhlak Learning to Grade VI students at Mi Islamiyah 1 Majasem, Kendal sub-district, Ngawi district. This study uses a descriptive qualitative research approach. The data collection methods used are interview, observation, and documentation methods. The data analysis method uses data reduction, data presentation, and conclusion drawing. The results of this study indicate that: (1) the stages of internalizing the value of akhlaqul karimah in students at MI Islamiyah 1 Majasem, especially in class VI students, which emphasizes the aspect of learning Akidah Akhlak. (2) Inhibiting and supporting factors in the process of internalizing the value of morality in learning Aqidah Akhlak in class VI students at MI Islamiyah 1 Majasem, inhibiting factors that arise from internal are the constraints of the face-to-face learning process due to the pandemic period and causing the internalization process to be hampered. While the supporting factors of the internalization process are helped by the role of the community in fostering students in exploring the science of morality. (3) The results of the process of internalizing the values of akhlaqul karimah show significant results, in which the role of parents is prioritized in the process of internalizing the values of akhlaqul karimah besides the role of educators is also very influential in the formation of morals of students.
\end{abstract}

Keyword: Internalization; akhlaqul karimah; students 
peserta didik di MI Islamiyah 1 Majasem khususnya pada peserta didik kelas VI, yang menekankan pada aspek pembelajaran Akidah Akhlak. (2) Faktor penghambat dan pendukung dalam proses internalisasi nilai akhlakul karimah dalam pembelajaran Aqidah Akhlak pada peserta didik kelas VI di MI Islamiyah 1 Majasem, faktor penghambat yang muncul dari internal yaitu terkendalanya proses pembelajaran tatap muka yang dikarenakan masa pandemi dan mengakibatkan proses penginternalisasian terhabat. Sedangkan faktor pendukung dari proses penginternalisasian terbantu oleh adanya peran masyarakat dala membina peserta didik dala mendalami ilmu akhlak. (3) Hasil dari proses penginternalisasian nilai akhlaqul karimah menunjukkan hasil yang signifikan, yang mana peran orang tua lebih di utamakan dalam proses penginternalisasian nilai akhlaqul karimah selain itu peran pendidik juga sangat berpengaruh dalam pembentukan Akhlak peserta didik.

Kata kunci: Internalisasi; akhlaqul karimah; siswa

\section{PENDAHULUAN}

Pada era digitalisai ini begitu pentingnya dalam menjaga keharmonisan dan menyelaraskan pembangunan dan kemajuan, maka nilai akhlak harus tetap dilestarikan dan ditanamkan kepada setiap manusia tanpa terkecuali peserta didik. Salah satu penanaman nilai tersebut adalah nilai pendidikan Akhlaqul Karimah. Pendidikan didesain sebaik mungkin agar para peserta didik mampumemahami dan menghayati nilai-nilai yang diajarkan. Permasalahan dunia pendidikan saat ini yang mendapat banyak sorotan adalah masalah karakter peserta didik yang tercermin dalam bentuk perilaku. Cara alternatif untuk mengatasi persoalan tersebut dan setidaknya dapat mengurangi masalah karakter tersebut adalah dengan menanamkan nilai-nilai Akhlakul Karimah pada peserta didik.

Dengan menanamkan nilai Akhlakul Karimah peserta didik dapat membangun generasi baru yang lebih baik dan berakhlak karimah sesuai dengan yang diharapkan. Pendidikan dasar merupakan jenjang pendidikan yang melandasi jenjang pendidikan menengah. Akhlakul Karimah merupakan cakupan moralitas atau perilaku yang baik pada setiap individu dalam melakukan aktivitasnya, begitu juga dengan peserta didik. Perilaku yang baik dan berakhlak diharapkan dapat tertanam dengan baik. Menanamkan nilai-nilai akhlaqul karimah dianggap sebagai alternative preventif karena dengan menanamkan nilainilai akhlaqul karimah tersebut dapat membangun generasi baru peserta didik yang lebih baik lagi. Sedangkan cara menanamkan nilai-nilai akhlaqul karimah salah satunya tidak lain dapat ditanamkan melalui pendidikan.

Pendidikan di Indonesia semua memilki titik tekan pada pembentukan akhlak mulia, pembentukan kepribadian atau watak bagi peserta didik. Kepribadian yang bertanggung jawab untuk peserta didik diharapkan dapat tertanam dengan baik dengan pengajaran sejak 
dini, pemahaman yang sudah diterapkan dari dini, pendidik yang selalu menerapkan dan memberikan contoh yang baik. Dengan menanamkan nilai-nilai akhlaqul karimah melalui pendidikan inilah diharapkan dapat mengembangkan kualitas generasi muda peserta didik dalam berbagai aspek yang dapat memperkecil dan mengurangi penyebab berbagai masalah karakter didunia pendidikan. Selain itu di masa kini disekitar kita, banyak sekali kita melihat perilakuanak yang kurang bahkan tidak memiliki akhlak yang terpuji, seperti tidak patuh kepada guruatau orang tuanya, tidak memiliki sopan santun, selalu melanggar peraturandan lain sebagainya. Semua hal tersebut bertentangan dengan tujuan pendidikan, khususnya Pendidikan Aqidah Akhlak.

Pendidikan agama islam sekarang lebih berorientasi pada belajar teorinya saja, sehingga banyak yang tidak mengetahui nilai-nilai ajaran agama, tetapi perilakunya tidak relavan dengan ajaran yang diketahuinya. Apa yang diajarakan mengenai Akhlak melalui pembelajaran Aqidah Akhlak dapat tersampaikan dengan baik dan semestinya. Pendidikan agama lebih banyak terkonsentrasi pada persoalan-persoalan teoritis keagamaan yang bersifat kognitif, dan kurang perhatian terhadap persoalan bagaimana mengubah pengetahuan agama yang kognitif menjadi "makna" dan "nilai" yang perlu diinternalisasikan dalam diri peserta didik lewat berbagai cara, media, dan forum. (Muhaimin, 2005). Berkaitan dengan hal tersebut, pendidik mempunyai peranan penting dalam mempersiapkan peserta didiknya agar tidak hanya cerdas atau pandai saja, tetapi harus bertaqwa, berakhlak mulia, bertanggung jawab, dan mempunyai etika yang baik. Guru memiliki peran yang sangat penting untuk menumbuh kembangkan kemampuan peserta didik dalam ranah kognitif, afektif, dan psikomotor, sekaligus dapat membentuk karakter akhlaqul karimah dalam kehidupan sehari-hari.

Dewasa ini problem pelajar pada peserta didik tingkat dasar atau madrasah adalah perilaku tercela yang sering diindikasikan yaitu pada perilaku misalnya, merokok, berkata kotor, menononton film pornografi, dan perilaku yang menyimpang lainnya yang tidak sesuai dengan norma masyarakat. Terlebih para remaja terutama pelajar adalah mudah terprovokasi yang tidak terkendali sehingga berujung pada tawuran antar pelajar, seperti yang diberitakan pada media cetak dan media massa. Di kota-kota besar pelajar terlibat dalam penyalahgunaan obat-obatan terlarang, seperti narkoba dengan berbagai jenisnya. Bahkan, stigma para pelajar saat ini diperparah oleh berbagai perilaku penyimpangan sosial yang mereka lakukan dalam bentuk pergaulan bebas seperti free sex, aborsi, homoseksual, lesbian, dan sebagainya. Kebiasaan ini sungguh menjadi hal yang sangat ironi jika dikaitkan 
dengan jati diri bangsa yang mengedepankan moral dalam kehidupan dan menjadi salah satu tugas besar para pendidik terkhusus pada ranah pendidikan Agama Islam. (Agus Zaenul Fitri, 2012) Internalisasi nilai-nilai akhlak memegang peranan penting dalam konteks kehidupan bersama karena salah satu tahap tingkah laku penyusuaian diri yang melahirkan gerak hati dalam bentuk tauhid, sabar, ikhlas dan sebagainya. Dengan terbentuknya kemampuan yang mendasar untuk mengambil dan bertingkah laku yang sesuai dengan norma dan sikap yang dikehendaki oleh agama dan masyarakat.

Pembahasan nilai-nilai akhlak ini bersifat abstrak dan memerlukan pengalaman yang panjang untuk memahaminya, sehingga pendidik maupun peserta didik dituntut untuk mampu berpikir secara abstrak yang umumnya sulit dilaksanakan. Internalisasi nilai-nilai akhlak dapat dilakukan dengan berbagai macam cara, salah satunya dengan pembiasaan. Dari uraian diatas, penulis mencermati pendidikan esensinya mampu memberikan kontribusi pada pembentukan jati diri generasi bangsa. Dalam konteks kehidupan yang demikian, pendidikan Islam dalam hal ini pada proses pembelajaran akidah akhlaq diharapkan lebih mampu dan memberikan solusi solutif yang sekaligus menjadi bahan evaluasi dan koreksi diri pada implementasi yang selama ini dilakukan, terutama pada siswa di Madrasah Ibtidaiyah. Karena persoalan pendidikan yang dihadapi oleh bangsa Indonesia saat ini bukan terkaitdengan persoalan kualitas sumber daya manusianya, namun lebih tepat pada sistem dan lingkungan pendidikan yang tidak mampu menunjang bagi perkembangan manusia secara maksimal. Secara paradigmatik, pembelajaran akidah akhlaq di madrasah perlu diorientasikan pada ajaran Islam yang rahmatan lil 'alamin. Islam yang memberi manfaat kepada siswa. Manfaat yang seharusnya tersampaikan pada peserta didik dapat dengan baik sampai pada peserta didik melalui pembelajaran Aqidah Akhlak.

Penelitian ini bertujuan untuk mengetahui penginternalisasian nilai-nilai akhlak dalam pembelajaran Akidah Akhlak pada siswa kelas VI di Mi Islamiyah 1 Majasem. setelah melihat Visi dan Misi Mi Islamiyah 1 Majasem yang mengunggulkan pendidikan ahklak, Memotivasi siswa agar menghayati dan mengamalkan agama yang dianutnya sebagai landasan dalam bertingkah laku dan berakhklak mulia. Maka dari itu peneliti ingin meneliti tentang internalisasi nilai-nilai akhlak dalam pembelajaran kidah Akhlak pada siswa kelas VI di Mi Islamiyah 1 Majasem. Pendekatan pembelajaran Akidah Akhlaq di Madrasah hendaknya dilakukan secara kontekstual, yaitu dikaitkan dengan konteks dan kebutuhan siswa yang dapat membantu mengatasi problem-problem nyata yang dihadapi, pembelajaran yang mampu memberi kesempatan kepada siswa untuk memahami dan 
mendiskusikan materi pelajaran. Bahkan, siswa difasilitasi untuk melakukan dan mengamalkan apa yang telah mereka pelajari dalam kehidupan sehari-hari. Proses penginternalisasian nilai Akhlaqul Karimah pada peserta didik umunya meiliki beberapa metode yang digunakan, adapun metode yang sangat dominan digunakan dalam penyampaian materi pembalajaran adalah metode demonstrasi, yang mana peran pendidik saat praktik langsung dicontoh oleh siswa. Selain itu peran orang tua dalam memberikan contoh juga tidak kalah penting karena madrasah kedua bagi para peserta didik ketika di luar madrasah adalah orang tua. Pembentukan nilai Akhlak pada anak, khususnya di Mi Islamiyah 1 Majasem pada peserta didik kelas VI mengalami hambatan dan dorongan, hambatan yang terjadi karena karena faktor internal yaitu kurangnya pengawasan dan penyampaian materi yang kurang maksimal dikarenakan masa pandemi.

Faktor pendukungnya pun datang dari peran masyarakat sekitar yang ikut serta mendidik para siswa agar selau senantiasa meneladani sifat terpuji yang selalu dicontohkan dala kehidupan sehari-hari. Seperti banyaknya tempat ngaji disekitar madrasah dan sekolah malam yaitu ngaji kitab. Lingkungan yang islami sangat mendukung dan membantu penanaman nilai-niali Akhlakul karimah. Proses internalisasi nilai-nilai akhlak dalam pembelajaran Akidah Akhlak pada kelas VI di Mi Islamiyah 1 Majasem guru melakukan pengajaran akhlak melalui dua cara yaitu materi-materi akhlak tidak hanya di sampaikan di dalam kelas tetapi juga di sampaikan di luar kelas seperti siswa di ajarkan bagaimana berperilaku baik dengan guru atau dengan teman sebaya, di ajarkan mentaati semua peraturan yang ada di sekolah. Dan metode-metode pembentukan akhlak siswa seperti metode kedislipinan, keteladanan, dan metode pembiasaan. Dengan proses internalisasi nilai-nilai akhlak dalam pembelajaran Akidah Akhlak guru mempunyai beberapa kendala seperti ada beberapa siswa yang kurang disiplin ketika pembelajaran berlangsung, dan siswa kurang berantusias ketika di arahkan mengikuti ekstrakurikuler keagamaan. Hal yang harus ditanamkan oleh pendidik dalam menginternalisasikan nilai-nilai akhlak yaitu guru harus memberikan kegiatan dan aturan serta pembiasaan di lingkungan sekolah dengan menciptakan kegiatan dan suasana religius di sekolah. Guru harus membimbing dan mengarahkan anak untuk selalu berperilaku yang baik serta memberikan motivasi kepada siswa untuk membekali siswa agar mempunyai akhlak yang mulia

Oleh karena itu, berdasarkan uraian diatas penulis melakukan suatu penelitian yaitu "Internalisasi NilaiAkhlaqul Karimah Dalam Pembelajaran Aqidah Akhlak Pada Siswa Kelas VI Di Mi Islamiyah 1 Majasem Kecamatan KendalKabupaten Ngawi” dengan harapan materi ini tidak 
hanya terbatas pada pengetahuan kognitif saja, tetapi bisa menjadi bagian yang tak terpisahkan dengan jiwa kepribadian seorang peserta didik, sehingga dapat terwujud menjadi sebuah karakter yang baik pada diri peserta didik dalam menjalani kehidupan yang penuh tantangan pada era globalisasi saat ini. Berdasarkan latar belakang di atas, maka penulis tertarik melakukan penelitian dengan berfokus pada aspek penginternalisasian nilai Akhlaqul Karimah dalam pembelajaran Aqidah Akhlak Pada Siswa Kelas VI Di Mi Islamiyah 1 Majasem Kecamatan Kendal Kabupaten Ngawi.

\section{METODE}

Metode penelitian menggunakan metode deskriptif. Pendekatan yang digunakan dalam penelitian ini adalah pendekatan kualitatif (Anggito \& Setiawan, 2018). Penelitian ini dilaksanakan di MI Islamiyah 1 Majasem. Data yang dianalisis berasal dari berbagai sumber baik data utama atau data pendukung melalui teknik observasi, wawancara, dan dokumentasi. Penelitian ini menekankan pada makna daripada generalisasi, sehingga penelitian ini menggunakan pendekatan kualitatif. Jenis penelitian ini ialah studi kasus dengan metode deskriptif. Studi kasus lebih dipahami sebagai pendekatan untuk mempelajari, menerangkan, dan menginterpretasikan suatu kasus dalam konteksnya yang alamiah tanpa adanya intervensi dari pihak luar (Arry Pongtiku, 2017). Tahapan-tahapan dalam melakukan penelitian, yaitu: tahap pra-lapangan, tahap pekerjaan di lapangan, tahap analisis data, dan tahap penulisan hasil penelitian.

\section{HASIL DAN BAHASAN}

\section{Hasil}

Proses Internalisasi Nilai Akhlaqul Karimah Dalam Pembelajaran Aqidah Akhlak Pada Siswa Kelas VI Di Mi Islamiyah 1 Majasem Kecamatan Kendal Kabupaten Ngawi, dilakukan dengan wawancara dan observasi kepada Kepala Madrasah, Guru Agama Islam dan orang tua peserta didik. Hasil wawancara dan observasi sebagai berikut.

1. Tahapan-tahapan internalisasi nilai Akhlaqul Karimah dalam pembelajaran Aqidah Akhlak pada siswa kelas VIdi MI Islamiyah 1 Majasem kecamatan Kendal Kabupaten Ngawi

Setelah melakukan wawancara dengan narasumber maka peneliti dapat menyimpulkan tahapan penginternalisasian mengenai nilai Akhlaqul Karimah peserta didik kelas VI di MI Islamiyah 1 Majasem. Dalam hasil wawancara yang peneliti lakukan dengan kepala Madrasah menununjukan bahwa akhlak yang tertanam dalam diri peserta didik khususnya siswa kelas VI ini sudah menunjukan Akhlak islami, yang mana hal ini telah 
disampaikan ibu kepala madrasah mengenai visi yang di jalankan serta rutinitas peserta didik di pebelajaran setiap harinya. Pernyataan serupa juga diungkapkan oleh bapak Untung shobirin selaku guru Agama Islam di MI Islamiyah 1 Majasem. Ada persamaan mengenai tahapan penginternalisasian nilai Akhlaqul Karimah pada peserta didik khususnya siswa kelas VI. Hasil tersebut menunjukkan keselarasan dengan hasil narasumber satu dan dua yakni: peran pendidik dan orang tua sangatlah berpengaruh dalam tahap penginternalisaian nilai-nilai Akhlaqul Karimah pada kehidupan bermasyarakat dan dalam kehidupan seharihari.

Dari hasil observasi yang peneliti lakukan dapat disimpulkan bahwa gambaran umum akhlak peserta didik khususnya siswa kelas VI di MI Islamiyah 1 Majasem sudah menerapkan nilai Akhlaqul Karimah. Hal ini dikarenakan penerapan nilai-nilai Akhlaqul Karimah di Madrasah sudah berjalan dengan baik, serta tahapan-tahapan dalam penanaman nilai Akhlaqul Karimah juga sudah terlaksana dengan baik pula. akan tetapi semua itu akan terus ditingkatkan dan dibantu dorongan dari orang tua peserta didik agar tetap ikut serta membina anak-anaknya disaat di luar jam pembelajaran Madrasah.

2. Faktor penghambat dan pendukung dalam internalisasi nilai Akhlaqul Karimah dalam pembelajaran Aqidah Akhlak pada siswa kelas VI di MI Islamiyah 1 Majasem kecamatan Kendal kabupaten Ngawi

Faktor penghambat dan pendukung dalam internalisasi nilai Akhlaqul Karimah pada siswa kelas VI di MI Islamiyah 1 Majasem didapatkan melalui wawancara. Hasil wawancara yang peneliti lakukan dapat diketahui bahwa faktor penghambat dan pendukung proses penginternalisasian nilai Akhalaqul Karimah pada peserta didik khususnya kelas VI di MI Islamiyah 1 Majasem tidak mengalai hambatan yang begitu besar. hal serupa juga di ungkapkan oleh bapak Untung Shobirin selaku guru Agama Islam. Hal senada juga disampaikan oleh Ibu Aminah selaku orang tua dari Ahmad Muzzaki siswa kelas VI di MI Islaiyah 1 Majasem Dari hasil wawancara dapat disimpulkan bahwa faktor penghambat dan pendukung proses penginternalisaian nilai Akhlaqul Karimah yang dilaksanakan oleh bapak/ibu guru serta wali murid menunjukan hasil yang sama, dimana peran pendidik dan oirang tua menjadi salah satu faktor pendukung yang paling utama. Sedangkan untuk faktor penghambatnya sendiri timbul karena kurangnya perhatian dan pengawasan langsung oleh pendidik dalam penyampaian Ilmu Aqidah Akhlak.

Dari hasil observasi yang peneliti lakukan selama penelitian, faktor penghambat dan pendukung dalam proses penginternalisasian nilai-nilai Akhlaqul Karimah pada para peserta 
didik khususnya siswa kelas VI di MI Islamiyah 1 Majasem, faktor penghambat dalam proses penginternalisasian terkendala dalam aspek peran pendidik yang kurang maksimal dikarenakan masih dalam masa pandemi. Sedangkan untuk faktor pendukungnya peran orang tua serta lingkungan masyarakat sekitar sangat berpengaruh dalam proses penginternalisasian nilai-nilai Akhlaqul Karimah. Hak ini karena keluarga adalah sebenarnya madrasah pertama bagi anak-anaknya. Sama seperti yang telah disampaikan wali murid dalam wawancara, bahwa orang tua lah yang paling pokok dalam mendidik dan mengawasi anaknya dalam kehidupan sehari-hari. Selain itu juga peran TPA (Taman Pendidikan Al Qur'an) dalam masyarakat sangat erat kaitanya dengan anak-anak. Maka hal ini dijadikan orang tua sebagai lebaga pembantu orang tua dalam membentuk sebuah Akhlak karimah pada peserta didik (anak).

3. Hasil dari internalisasi nilai Akhlaqul Karimah dalam pembelajaran Aqidah Akhlak pada siswa VI di MI Islamiyah 1 Majasem kecamatan Kendal Kabupaten Ngawi

Sesuai dengan hasil wawancara antara peneliti dengan narasumber dapat diperoleh hasil dari proses penginternalisasian nilai Akhlaqul Karimah dalam pembelajaran Aqidah Akhlak. Dari hasil wawancara yang peneliti lakukan dapat diketahui bahwa hasil dari penginternalisasian nilai Akhlaqul Karimah sudah berjalan dengan baik. Hal ini juga serupa seperti yang diungkapkan oleh bapak Untung Sobirin. Hal serupa juga disampaikan oleh ibu Aminah selaku orang tua dari Ahmad Mudzaky siswa kelas VI di MI Islamiyah 1 Majasem kecamatan Kendal kabupaten Ngawi. Dari hasil wawancara, peneliti dapat menyimpulkan bahwa, hasil penginternalisasian nilai-nilai Akhlaqul karimah pada siswa kelas VI MI Islaiyah 1 Majasem menunjukkan hasil yang baik.

Dari hasil observasi yang peneliti lakukan selama dilingkungan Madrasah juga menunjukkan hasil yang sangat positif. Hal ini juga selaras dengan hasil observasi yang peneliti lakukan selama di linkungan sekitar madrasah (Dusun Krajan).

\section{Bahasan}

Pembahasan hasil dari internalisasi nilai Akhlaqul Karimah dalam pembelajaran Aqidah Akhlak pada siswa kelas VI di MI Islamiyah 1 Majasem kecamatan Kendal Kabupaten Ngawi, sebagai berikut:

1. Analisis tentang tahapan-tahapan internalisasi nilai Akhlaqul Karimah dalam pembelajaran Aqidah Akhlak pada siswa kelas VI di MI Islamiyah 1 Majasem kecamatan Kendal Kabupaten Ngawi

Jurnal yang ditulis oleh Izha, dkk. (2020) dengan judul "Internalisasi Nilai-Nilai 
Spiritual Dalam Pembentukan Akhlakul Karimah Peserta Didik Di Smp Islam Ma'arif 02 Malang". Pada penelitian ini menjelaskan tentang internalisasi nilai-nilai spiritual dalam pembentukan Akhlaqul Karimah peserta didik dilakukan melalui program-program keagamaan. Program-program keagamaan tersebut diantaranya adalah sholat dhuhur dan sholat ashar berjamaah, sholat dhuha, istighosah, membaca yasin, tahlil dan sholawat serta kegiatan madrasah diniyah. Program-program tersebut dipantau dan dibimbing langsung oleh guru yang kompeten dalam bidangnya. Metode yang digunakan dalam propses internalisasi nilai-nilai spiritual adalah etode keteladanan dan metode pembiasaan. Metode keteladanan dilakukan dengan memberikan contoh langsung kepada siswa dewngan memberikan arahan bimbingan yang sesuai dengan program-program keagamaan tersebut. Sedangkan metode pembiasaan dilakukan dengan kegiatan keagamaan yang pelaksanaannya secara terus-menerus dan rutin dilakukan. (Izha, dkk., 2020) Perbedaan dengan penelitian yang akan penulis lakukan terletak pada objek yang akan diteliti jika penelitian tersebut dilakukan pada peserta didik tingkat SMP, sedangkan penelitian yang penulis lakukan berobjek pada peserta didik tingkat sekolah dasar (Madrasah Ibtidaiyah). Sedangkan persamaannya terletak pada pembentukan nilai karakter.

Tahapan-tahapan internalisasi nilai Akhlaqul Karimah di MI Islamiyah 1 Majasem memiliki beberapa tahapan diantaranya: Tahap transformasi nilai: Tahap ini merupakan suatu proses yang dilakukan oleh pendidik dalam menginformasikan nilai-nilai yang baik dan kurang baik. Pada tahap ini hanya terjadi komuniasi verbal antara guru dan siswa. Tahap transaksi nilai: Suatu tahap pendidikan nilai dengan jalanmelakukan komunikasi dua arah atau interaksi antara siswa dengan pendidik yang bersifat timbal balik. Tahap transinternalisasi tahap ini jauh lebih mendalam dari tahaptransaksi. Pada tahap ini bukan hanya dilakukan dengan komunikasi verbal tapi juga sikap mental dan kepribadian. Pada tahap ini komunikasi kepribadian yang berperan secara aktif.

Proses penginternalisasian nilai Akhlaqul Karimah pada pembelajaran Akidah Akhlak di MI Islamiyah 1 Majasem sudah berjalan dengan baik, tahapan-tahapan tersebut di internalisasikan oleh pendidik di Madrasah baik di dalam maupun di luar Madrasah. Tahaptahap internalisasi nilai dari Krathwhol (Soedijarto,1993) tersebut oleh dikerucutkan menjadi tiga tahap yaitu: tahap pengenalan dan pemahaan, dalam tahap pengenalan dan pemahaman sendiri memiliki beberapa metode yaitu: ceramah, penugasan dan diskusi. Tahap penerimaan dan tahap pengintegrasian. Sejalan dengan tahapan-tahapan yang diinternalisasikan di Mi Islamiyah 1 Majasem yang menggunakan teori Kratwhol tersebut, 
yaitu dengan menerapkan tahapan pengenalan dan pemahaman yang di dalamnya memiliki metode ceramah, penugasan dan diskusi.

Tahapan yang dilaksanakan di Mi Islamiyah 1 Majasem sudah selaras dengan teori yang peneliti gunakan yaitu teori Kratwhol (Soedijarto,1993) yang menekankan pada aspek pengenalan dan peahaman, tahap penerimaan dan tahap pengintegrasian. Selain hal itu peserta didik di Mi Islamiyah 1 Majasem khususnya kelas VI sudah dapat menerapkan tahapan-tahapan yang telah di internalisasikan oleh pendidik untuk membentuk Akhlaqul Karimah dan dapat diamalkan dalam kehidupan sehari-hari.

2. Analisis tentang faktor penghambat dan pendukung dalam internalisasi nilai Akhlaqul Karimah dalam pembelajaran Aqidah Akhlak pada siswa kelas VI di MI Islamiyah 1 Majasem kecamatan Kendal kabupaten Ngawi

Penelitian yang di tulis oleh, Wibawati Bermi dengan judul "Internalisasi Nilai-Nilai Agama Islam Untuk Membentuk Sikap Dan Perilaku Siswa Sekolah Dasar Islam Terpadu Al-Mukminun Ngrambe Ngawi” Pada penelitian ini menjelaskan perkembangan sikap dan perilaku pada siswa SDIT Al-Mukminun Ngrambe adalah sikap dan perilaku siswa kepada Allah menunjukkan adanya perubaha tingkah laku yang cukup signifikat, bila dibandingkan dengan perkebangan sikap dan perilaku siswa SD pada umumnya. Kesaadaran akan adanya Allah telah mulai tumbuh pada diri siswa yang diwujudkan dengan ketaatan dan keyakinan kepada Allah. Ketaatan tersebut terlihat dari kesadaran siswa dalam kehidupan sehari-hari yang ditandai dengan ketaatan beribadah, berzikir, bertadarus Al-Qura'an, senantiasa berdoa dan bersukur kepada Allah, berpiuasa penuh dibulan ramadhan dan berinfaq kepada Allah. (Wibawati Bermi, 2016) Perbedaan dengan penelitian yang akan penulis lakukan terletak pada aspek fokus penelitian, yaitu jurnal ini memfokuskan pada pendidikan agama untuk pembentukan kareakter siswa sedangkan penelitian yang penulis teliti yang memfokuskan pada pendidikan Akhlaqul Karimah. Sedangkan persamaannya terletak pada proses pembentukanb karakter peserta didik

Proses penginternalisasian nilai Akhlaqul Karimah pada peserta didik kelas VI di MI Islamiyah 1 Majasem pada dasarnya sudah berjalan dengan baik, akan tetapi di samping itu ada beberapa peserta didik yang mungkin belum bisa menempatkan nilai Akhlak di atas segalanya karena masih terpengaruh oleh masa kekanak-kanakan. Para pendidik sendiri juga sudah menyiapkan metode tersendiri untuk anak yang mungkin dikatakan masih dibawah umur/ kekanak-kanakan tersebut.

Selain para pendidik, peran orang tua dalam proses penginterlaisaian nilai Akhlaqul 
karimah juga sangat diperlukan, karena seorang anak akan lebih lama belajar pada kehidupan keluarga dibandingkan dengan pembelajaran yang diberikan di Madrasah. Peran orang tua dalam penginternalisasian nilai Akhlaqul Karimah juga dapat terbantu dengan adanya TPA (Taman pendidikan Al Qur'an) yang ada di desa/ tempat masyarakat tinggal.

Dari hasil wawancara dengan para guru di Mi Islamiyah 1 Majasem bahwa pelaksaan internalisasi nilai-nilai Akhlaqul Karimah untuk meningkatkan karakter siswa terdapat faktor-faktor yang menghambat baik dari Internal ataupun Eksternal.

Faktor Internal dari observasi dan wawancara peneliti kepada para guru di $\mathrm{Mi}$ Islamiyah 1 Majasem bahwa faktor penghambat dari dalam diri siswa sendiri karena karakter siswa yang berbeda-beda dan dari latar belakang siswa yang berbeda beda sehingga dalam proses pembinaan yang dilakukan oleh para guru kadang tidak berjalan baik dengan adanya siswa yang dapat mengerti dan melakukan dengan baik pembinaan tersebut dan adanya siswa yang tidak dapat mengerti serta tidak dapat melakukan pembinaan tersebut dengan baik.

Faktor Eksternal banyak faktor penghambat yang mempengaruhi internalisasi nilainilai Akhlaqul Karimah untuk meningkatkan karakter siswa dari luar diri para siswa yaitu: Keluarga, lingkungan sekolah, media informasi, masyarakat. Faktor utama dalam mempengaruhi semua psikologis dan tingkah laku siswa karena keluarga adalah proses pendidikan yang pertama kali dilakukan. Jika keluarga tidak mendukung terhadap program yang dilakukan siswa disekolah maka proses internalisasi nilai-nilai agama untuk meningkatkan karakter siswa itu akan sia-sia Dalam lingkungan sekolah ini terdapat kepala sekolah, guru, dan siswa yang juga bisa menjadi faktor penghambat proses internalisasi nilai-nilai Akhlaqul Karimah. Dari hasil wawancara dengan para guru dan siswa bahwasanya ada beberapa guru yang tidak menghiraukan para siswa karena terlalu sibuk dengan pekerjaanya sehingga ketika untuk melakukan kegiatan sholat berjama'ah kadang para siswa tidak segera ambil wudlu ketika waktu kegiatan sholat berjama'ah berlangsung.

Jurnal yang ditulis oleh Siti Muzianah dengan judul "Upaya Guru Dalam Menginternalisasikan Nilai-Nilai Pendidikan Agama Islam Bagi Pembentukan Akhlakul Karimah Di SDITAs Sunnah Kota Cirebon”. Pada penelitian ini menjelaskan tentang upaya guru dalam mengimplementasikan model internalisasi nilai di SDIT As Sunnah kota Cirebon sudah baik, terlihat dari upaya sekolah yang menyediakan lingkungan pondok pesantren yang agamis, guru-guru yang memahami proses internalisasi nilai akhlaqul karimah yang baik, dengan cara membimbing dan mengajar siswa, sekaligus menjadi 
suritauladan yang baik bagi siswa pada proses penginternalisasiannya yaitu dimana pendidik menjadi faktor terpenting. (Siti Muzianah, 2017) Perbedaan dengan penelitian yang akan penulis lakukan yaitu terletak pada aspek fokus penelitian, yaitu jurnal ini memfokuskan pada pendidikan agama untuk pembentukan kareakter siswa sedangkan penelitian yang penulis teliti yang memfokuskan pada penginternalisasian nilai-nilai Akhlaqul Karimah. Sedangkan persamaannya yaitu terletak

Selain hal itu, faktor penghambat dari media informasi juga sangat berpengaruh, media ini merupakan salah satu kebutuhan utama yang bisa menjadi faktor penghambat proses internalisasi terhadap para siswa, seperti Komputer, internet, Handphone, majalah dan lain sebagainya jika tidak dimanfaatkan dengan baik maka bisa mempengaruhi para siswa kedalam hal yang negative. Yang terakhir penghambat dari masyarakat, Masyarakat merupakan faktor penghambat dari internalisasi nilai-nilai Akhlaqul Karimah karena masyarakat merupakan tempat mereka bersosialisasi dalam kehidupannya jadi bila masyarakat ditempat mereka bersosial tidak islami dan tidak baik secara tidak sadar mereka akan memberikan kesan yang kurang baik dalam diri siswa tersebut.

Faktor penghambat dan pendukung dalam proses penginternalisasian nilai Akhlaqul Karimah terjadi karena adanya beberapa aspek, hambatan yang dialami dalam proses penginternalisasian terjadi karena masa pandemi yang kita alami saat ini. Maka dari itu peran pendidik menjadi berkurang dalam penyampaian, pengawasan dan pengarahan. Sedangkan untuk pendukungnya sendiri timbul dari peran orang tua dan masyarakat sekitar dalam proses pembentukan nilai Akhlaqul Karimah yang mana sangat berpengaruh positif dalam penginternalisasian nilai-nilai Akhlaqul Karimah.

3. Analisis tentang hasil dari internalisasi nilai Akhlaqul Karimah dalam pembelajaran Aqidah Akhlak pada siswa VI di MI Islamiyah 1 Majasem kecamatan Kendal kabupaten Ngawi

Jurnal yang ditulis oleh Utomo (2017) dengan judul "Internalisasi Nilai-Nilai Akhlaqul Karimah Siswa Pada Pembelajaran Akidah Akhlak di Madrasah Ibtidaiyah Kecamatan Windusari Kabupaten Magelang" Hasil penelitian ini menunjukkan bahwa pembelajaran Aqidah Akhlak meliputi aspek keimanan, ihsan, taqwa, ikhlas, syukur melalui pembelajaran dikelas. Selain itu juga dilakukan beberapa kegiatan keagamaan yang ditanamkan, seperti peringatan Hari Besar Islam, peringatan mauled nabi, kebiasaan sholat dhuha dan sholat dzuhur berjamaah. Ada beberapa tahap intenalisasi dalam penelitian ini: 1) Tahapan pengenalan dan pemahaman yaitu bagaimana peserta didik mulai tertarik 
memahami dan menghargai pentingnya nilai-nilai Akhlaqul Karimah bagi dirinya terwujud dalam pertemuan dalam jam belajar. 2) Tahapan penerimaan seperti hal-hal yang menjadi sarana dalam proses internalisasi nilai-nilai Akhlaqul Karimah khususnya dalam kegiatan keagamaan, tata tertib, lingkungan benda, peneladanan, pembiasaan serta dorongan dorongan dalam memberikan motivasi melalui pemberian penghargaan dan pujian terhadap siswa untuk mengamalkan nilai-nilai Akhlaqul Karimah. (Utomo, 2017) Perbedaan dengan penelitian yang penulis lakukan adalah terletak pada fokus penelitian yang mendasar pada nilai Akidah Akhlak. Sedangkan persamaanya terletak pada objek yaitu pada sasaran siswa Madrasah Ibtidaiyah (MI).

Jurnal yang ditulis oleh Syahfitra dan Asro (2019) dengang judul "Internalisasi Nilai Nilai Akhlaqul Karimah Dalam Kehidupan Sehari-Hari Siswa Sd Negeri 1 Cibugel”. Hasil penelitian ini menunjukkan bahwa siswa memiliki antusias dan partisipasi yang tinggi menjadi insan yang lebih baik, hal ini terbukti secara implisit dalam kegiatan sosialisasi yang telah dilaksanakan, dimana hal ini secara tersirat menunjukkan perkembangan akhlaq siswa dalam menghargai orang lain. (Syahfitra \& Asro, 2019). Perbedaan dengan penelitian yang akan penulis lakukan terletak pada tempat yang akan diteliti dan objek yang di teliti, jika penelitian tersebut dilakukan pada peserta didik di SD, sedangkan penelitian yang penulis lakukan berobjek pada peserta didik tingkat MI (Madrasah Ibtidaiyah).Sedangkan persamaanya terletak pada tujuan penelitian yang sama-sama bertujuan pembentukan nilai karakter peserta didik.

Hasil dari internalisasi nilai Akhlaqul Karimah dalam pembelajaran Aqidah Akhlak menunjukkan hasil yang bervariatif, disamping hal itu peran pendidik (pembelajaran Aqidah Akhlak) serta orang tua sangat berpengaruh dalam proses penginternalisasian nilai akhlaqul karimah. Para peserta didik dapat menerapkan nilai Akhlak apa bila dua peran tadi dapat berkontribusi dengan maksimal. Untuk memperoleh hasil yang maksimal penekanan pada aspek perilaku dalam kehidupan bermasyarakat harus lebih ditingkatkan.

Berdasarkan proses internalisasi nilai-nilai Akhlakul Karimah yang sudah dipaparkan dan dijelaskan di atas peneliti menggunakan metode observasi, dokumentasi, dan wawancara langsung dengan kepala madrasah, Guru dan wali murid. Bahwa perubahan tidak terjadi langsung, tetapi sedikit demi sedikit peserta didik tersebut benar-benar mempunyai akhlak yang lebih baik dan meningkatkan spiritual santri yaitu melalui beberapa metode yang diterapkan diantaranya yaitu metode pembiasaan, metode keteladanan, metode 
bimbingan, serta metode motivasi atau dorongan terhadap kegiatan-kegiatan islami dan rutinan yan gada di Madrasah Ibtidaiyah Islamiyah 1 Majasem.

Peningkatan spiritual peserta didik dapat dilihat dari perilaku peserta didik yang spontan melakukan hal-hal baik tanpa ada dorongan dari luar, tingkat kesadaran diri yang tinggi terhadap sesuatu, dan setelah mendapat pelajaran baru pasti direnungkan dan diterapkan, hal ini sesuai dengan teori karakteritik peningkatan spiritual yang dikemukakan oleh Robert A. Emmos dalam Sugeng Sejati yaitu sebagai berikut: Kemampuan individu yang mempunyai tingkat kesadaran yang memuncak, Kemampuan individu mensakralkan pengalaman sehari-hari, Kemampuan individu untuk berbuat baik, yaitu memiliki rasa kasih sayang yang tinggi pada sesama makhluk tuhan seperti, memberi ma'af, bersyukur, atau mengungkapkan trimakasih, bersikap rendah hati, menunjukkan kasih sayang dan kearifan, hanyalah sebagian dari kearifan.

Dari beberapa uraian di atas mengenai hasil internalisasi nilai-nilai Akhlakul Karimah dalam meningkatkan spiritual siswa maka, peneliti menyimpulkan bahwa spiritual siswa meningkat dengan baik. Peningkatan spiritual mengacu pada teori Robert A. Emmos dalam Sugeng Sejati yang mengemukakan bahwa karakteritik peningkatan spiritual ada 3 dan sudah dijelaskan di atas. Dari ketiga karakteristik tersebut diterapkan dengan 4 metode yaitu metode pembiasaan, metode keteladanan, metode bimbingan, serta metode motivasi atau dorongan dalam melaksanakan kegiatan-kegiatan di Madrasah Ibtidaiyah Islamiyah 1 Majasem.

Hasil dari proses penginternalisasian nilai-nilai Akhlaqul Karimah dalam pembelajaran Akidah Akhlak pada siswa kelas VI di MI Islamiyah 1 Majasem kecamatan Kendal kabupaten Ngawi menunjukan hasil yang sangat baik, hal ini dapat dibuktikan dengan adanya penelitian ini yang mana penelitian ini membahas bagaimana tahapantahapan, faktor penghambat dan pendukung serta hasil akhir dari proses penginternalisasian nilai-nilai Akhlaqul Karimah.

Setelah melakukan penelitian selama di lapangan dan observasi serta wawancara dengan beberapa narasumber, dapat ditarik kesimpulan bahwa nilai Akhlaqul Karimah yang dimiliki para peserta didik di Mi Islamiyah 1 Majasem khususnya kelas VI memberikan hasil yang baik. Hasil penginternalisasian nilai Akhlaqul Karimah pada siswa kelas VI di MI Islamiyah 1 Majasem sudah menunjukkan hasil yang positif dan maksimal, hal ini dibuktikan dengan adanya peran siswa dalam kehidupan sehari-hari yang selalu 
mengedepankan Akhlak dan selalu menjunjung tinggi nilai kesopan santunan terhadap orang tua serta saling menghargai terhadap sesama.

\section{KESIMPULAN}

Berdasarkan pembahasan yang telah diuraikan diatas, maka dapat disimpulkan bahwa:

1. Bentuk Problema Konseling Multikultural di di SMP Negeri 8 Rejang Lebong adalah konselor harus benar-benar sesuai dengan budaya konseli karena realitas lingkungan siswa yang beragam menjadi problem bagi konselor sehingga konselor harus benar-benar memahami berbagai macam budaya yang dimiliki oleh siswa.

2. Kendala-Kendala dalam Melaksanakan Konseling Multikultural pada Siswa SMP Negeri 8 Rejang Lebong diantaranya yaitu masih kurangnya kerjasama orang tua terhadap siswa yang bermasalah, kurangnya partisipasi antar guru dengan siswa, adanya perbedaan budaya pada siswa yang mengharuskan guru BK memahami budaya-budaya siswa yang berbeda-beda tersebut.

3. Upaya Konselor dalam Menangani Problematika Konseling Multikultural di SMP Negeri 8 Rejang Lebong dilakukan dengan cara meningkatkan pelaksanaan konseling multikultural, meningkatkan kerjasama dengan guru dan orangtua, memanfaatkan media dalam konseling multikultural dan memberikan bimbingan nilai-nilai karakter berdasarkan agama.

\section{DAFTAR RUJUKAN}

Izha, A., Murtadho, M., Sudrajat, A. (2020). Internalisasi Nilai-Nilai Spiritual Dalam Pembentukan Akhlakul Karimah Peserta Didik Di Smp Islam Ma'arif 02 Malang. Jurnal pendidikan Islam, 5(6), 1-8.

Syahfitra, A. \& Asro, M. (2019) Internalisasi Nilai Nilai Akhlaqul Karimah Dalam Kehidupan Sehari-Hari Siswa Sd Negeri 1 Cibugel. Jurnal Ilmiah Pengabdian Kepada Masyarakat, 2(2), 58-66.

Anggito, A. \& Setiawan, J. (2018). Metodologi Penelitian Kualitatif. Jawa Barat: Jejak.

Fitri, A. Z. (2012). Pendidikan Karakter Berbasis Nilai dan Etika di Sekolah Yogyakarta: Ar-Ruzz Media.

Mahjuddin. (1995). Membina Akhlak Anak. Surabaya: Al Ikhlas.

Muhaimin. (2005). Pengembangan Kurikulum Pendidikan Agama Islam: di Sekolah, Madrasah,dan Perguruan Tinggi. Jakarta: PT. Raja Grafindo Persada.

Pusat Pembinaan dan Pengembangan Bahasa Departement Pendidikan dan Kebudayaan. (1989). Kamus Besar Bahasa Indonesia. Jakarta: Balai Pustaka.

Pongtiku, A., (2017). Metode Penelitian Kualitatif. Bogor: In Media.

Sa'addudin, Mukmin, A. I., Ali, D.S. (2006). Meneladani Akhlak Nabi. Bandung: Remaja 
Rosda Karya.

Sanjaya, W. (2014). Penelitian Pendidikan: Jenis, Metode, dan Prosedur. Jakarta: Kencana.

Utomo, S. (2017). Internalisasi Nilai-Nilai Akhlaqul Karimah Siswa Pada Pembelajaran Akidah Akhlaq Di Madrasah Ibtidaiyah Kecamatan Windusari Kabupaten Magelang, Jurnal Penelitian, 11(1), 55-68.

Muzainah, S. (2017). Upaya Guru Dalam Menginternalisasikan Nilai-Nilai Pendidikan Agama Islam Bagi Pembentukan Akhlakul Karimah Di SDITAs Sunnah Kota Cirebon. Jurnal ilmiah kajian Islam, 2(1), 60-77.

Soedijarto. (1993). Menuju Pendidikan Nasional Yang Relevan Dan Bermutu. Jakarta: Balai Pustaka.

Bermi, W. (2016). Internalisasi Nilai-Nilai Agama Islam Untuk Membentuk Sikap Dan Perilaku Siswa Sekolah Dasar Islam Terpadu Al-Mukminun Ngrambe Ngaw. Jurnal Al Lubab, 1(1), 1-13.

Ya'qub, H. (1983). Etika Islam (Pembinaan Akhlakul Karimah). Bandung: CV. Diponegoro. 